\title{
Wives' Employment and Marital Dissolution: Consideration of Gender Ideology and Marital Interaction
}

\author{
Deniz Yucel \\ Department of Sociology, William Paterson University of New Jersey, Wayne, USA \\ Email: yuceld@wpunj.edu
}

Received December $8^{\text {th }}, 2011 ;$ revised January $17^{\text {th }}, 2012$; accepted February $22^{\text {nd }}, 2012$

\begin{abstract}
This study examines both the mediating effects of marital interaction and gender ideology, as well as the moderating effect of gender ideology in understanding the relationship between wives' work hours and marital dissolution. This paper also explores the role of gender for couples who disagree in their relationship assessments. Wives' additional work hours are positively associated with marital dissolution, an effect that operates through increased gender egalitarianism (for both spouses and for wives only) and decreased marital interaction (for both spouses and for wives only). Lastly, for couples who differ in their reports of gender ideology and marital interaction, the likelihood of marital dissolution is contingent upon wives' assessments of their relationship. The implications of this study and the avenues for future research are also discussed.
\end{abstract}

Keywords: Wives’ Employment; Marital Dissolution; Gender Ideology; Marital Interaction

\section{Introduction}

Wives' employment has long been studied and considered as one determinant of marital instability (Booth, Johnson, White, \& Edwards, 1984; Greenstein, 1990, 1995; Johnson, 2004; South \& Spitze, 1986; Spitze \& South, 1985). However, scholars do not yet agree about the underlying mechanisms that link wives' work hours to marital dissolution. Using three theoretical frameworks-the attachment hypothesis (Hill, 1988), role strain theory (Goode, 1960), and the ideological consistency argument (Ross \& Sawhill, 1975) - this study tests how and when wives' work hours are associated with marital dissolution (i.e., the mediating and moderating mechanisms). Specifically, this study explores: 1) whether there is a direct relationship between wives' work hours and marital dissolution; 2) whether couples' marital interaction mediates the effect of wives' work hours on marital dissolution (testing the attachment hypothesis); 3) whether couples' gender ideology mediates the effect of wives' work hours on marital dissolution (testing role strain theory); 4) whether couples' gender ideology moderates the relationship between wives' increased work hours and marital dissolution (testing the ideological consistency hypothesis); and 5) whether, among couples with conflicting reports, marital dissolution depends on the spouses' respective assessments of the relationship. Here, marital interaction is defined as the amount of any time spent between spouses, while gender ideologies denote "how a person identifies herself or himself with regard to marital and family roles that are traditionally linked to gender" (Greenstein, 1996b: p. 586). I tested these five questions using nationally representative data from the first two waves of the National Survey of Families and Households (NSFH). NSFH is a nationally representative dataset that is designed to provide a broad range of information on family life, to serve as a resource for research across disciplinary perspectives. Each "wave" of data represents a time when interviews (in this case, with couples) are conducted. In this study, I used the first two waves: interviews in 1987-1988 (first wave) and in
1992-1994 (second wave).

\section{Literature Review and Hypotheses}

\section{Wives’ Work Hours and Marital Dissolution}

Most prior studies have confirmed that wives' work hours are positively associated with marital dissolution (Booth et al., 1984; Johnson, 2004; South \& Spitze, 1986; Spitze \& South, 1985). Some other research, however, has tested the reverse relationship: the effect of anticipated divorce risk on labor supply (Greene \& Quester, 1982; Montalto \& Gerner, 1998; Sen, 2000). Sen (2000) constructs a longitudinal dataset and compares two cohorts: the National Longitudinal Survey of Young Women NLSYW for 1968-1983 and the National Longitudinal Survey of Youth (NLSY) 1979 for 1979-1993. Her measure of divorce risk was a dummy variable indicating whether divorce or separation occurred in the next three years. Her results suggest that the risk of divorce significantly increased the labor supply, but by less in the more recent cohort.

Despite these inconsistent findings, only a few studies have tested the mediating and moderating mechanisms of this association (Greenstein, 1995; Poortman, 2005; Spitze \& South, 1985). This study makes a contribution to research by including couple-level measures of marital interaction and gender ideology, and by testing the mediating effects of couples' gender ideology and marital interaction, and the moderating effect of couples' gender ideology, to explain the relationship between wives' work hours and marital dissolution. I expect to find a significant and positive relationship between wives' work hours and marital dissolution, even after controlling for couples' characteristics (Hypothesis 1).

\section{The Mediating Effect of Marital Interaction-Testing} the Attachment Hypothesis

According to the attachment hypothesis, marital interaction is 
one of the key factors that affect marital stability. Couples who interact fewer hours per week are more likely to have a failed marriage (Spitze \& South, 1985). Prior research also has shown that employed mothers have a more strained experience of balancing work-family roles, and that marital interaction and quality are compromised when dual-earner couples have children (Hill, 1988; Kingston \& Nock, 1987; Voydanoff, 1988). Consistent with the attachment hypothesis, Hill (1988) argued that pleasurable, shared time is marriage-specific capital that discourages divorce. Her study of the use of leisure time, in relation to marital dissolution five years later, supports this argument. Indeed, in multivariate models that include both spouses' earnings and gender role conflicts, a lack of leisure time is second only to short marital duration in increasing the risk of divorce.

On the other hand, a limited number of studies have found that marital interaction has no mediating effect between wives' work hours and an increased divorce risk (Poortman, 2005). Poortman, however, suggested an explanation for this insignificant effect. First, her study was based on a sample from the Netherlands, which is characterized by a strong welfare system and a strong focus on family life. According to Poortman, we might expect the mediating effect (if any) to be smaller in such a sample. Second, her study was limited to couples in their early marriage; she argues that marital interaction is usually more important during early marriage. Nevertheless, some research has suggested that the effect of marital interaction on marital quality is stronger in long-term marriages (Schmitt, Matthias, \& Shapiro, 2007), and that the mediating effect of marital interaction on the association between wives' work hours and marital dissolution is likewise stronger in long-term marriages (Yucel, 2012). Despite these inconsistent findings, I expect to find that couples' marital interaction mediates the effect of wives' employment hours on marital dissolution (Hypothesis 2).

\section{The Mediating and Moderating Effect of Gender Ideology-Testing Role Strain Theory and Ideological Consistency Hypothesis}

Goode's role strain theory (1960) suggests that people cannot perform as effectively when they are given different roles to play. Women's paid employment may influence their ideological support for gender equality by increasing their exposure to social networks that support gender equality, and by providing them with a greater stake in improving women's economic position (Bolzendahl \& Myers, 2004). In addition, many studies have found that paid employment increases women's support for an equal division of domestic roles between men and women (Coverdill, Kraft, \& Manley, 1996; Davis \& Greenstein, 2009; Fan \& Marini, 2000; Huber \& Spitze, 1981; Minnotte, Minnotte, Pederson, Mannon, \& Kiger, 2010). This gender egalitarianism might lead to strain between wives' work and family roles, leading to more dissatisfaction with the gendered division of labor - which may in turn lower marital quality and increase marital dissolution. Consistent with these approaches, research has found that gender ideology mediates the effect of wives' employment on marital dissolution (Greenstein, 1995; Sayer \& Bianchi, 2000). Overall, I expect to find that the effect of wives' work hours on marital dissolution operates through wives being more supportive of gender equality than their husbands are (Hypothesis 3).

The effect of wives' work hours on marital dissolution may also be contingent on couples' gender ideology. Gender ideology defines expectations about the "appropriate" male and female marital roles (Greenstein, 1995, 1996a). The ideological consistency argument (Ross \& Sawhill, 1975) suggests that inconsistency between these gender ideologies and marital roles decreases marital stability. Previous studies have explored the moderating effect of gender ideology on marital dissolution (Greenstein, 1995; Spitze \& South, 1985). These studies found that the effect of wives' work hours on divorce is stronger and indeed only significant for couples in which the husband disapproved of his wife working (Spitze \& South, 1985). Research found that wives' work hours have no significant effect on marital dissolution when wives support traditional gender ideology, a nearly statistically significant effect for women with moderate gender ideology, and a strong positive effect on marital instability for non-traditional women (Greenstein, 1995).

Other studies have found that gender ideology has a moderating effect on marital quality (Greenstein, 1996a; Nordenmark \& Nyman, 2003). Greenstein (1996a) found that inequalities in the division of household labor were strongly related to perceptions of inequality, which were then related to the perceived quality of the marital relationship. The results in this study suggest that these associations are significantly stronger for egalitarian wives than they are for traditional wives. Therefore, I expect to find that the effect of wives' work hours on marital dissolution is strongest when wives hold more egalitarian views than their husbands. In other words, I predict that when the wives have a more egalitarian gender ideology than their husbands, an increase in wives' work hours will be a destabilizing force in their marriage, leading to a higher likelihood of marital dissolution. Conversely, I predict that when wives have a more traditional gender ideology than their husbands, an increase in wives' work hours will have less or no effect on the likelihood of divorce (Hypothesis 4).

\section{The Role of Gender}

The family has always been a gendered institution, and research suggests that the characteristic roles of husbands and wives have different influences on marital disruption. Specifically, Heaton and Blake (1999) found a positive relationship between marital disagreement and marital dissolution for both spouses, as well as a negative relationship between marital happiness and marital dissolution for both spouses; the wives' coefficients were significantly higher than the husbands'. They concluded that wives' evaluations of marital quality are better predictors of marital dissolution than their husbands'. However, Sanchez and Gager (2000) and Gager and Sanchez (2003) found the opposite result: husbands' negative perceptions of disagreements and unhappiness were better predictors of marital dissolution than were negative reports by the wives. They argued that wives' views might be discounted in their relationships and that wives might experience less marital power, higher barriers to leaving a marriage, and fewer alternatives to their current situation. Hochschild (1989) argues that gender inequality in society has an impact on wives' expectations of their marriages such that, despite their desire for equality and personal satisfaction in their marriages, they cannot fight for equality and feel pressured to disregard negative feelings.

Past research also concludes that the financial consequences of divorce might be more severe for wives than for husbands (Duncan \& Hoffman, 1985; Holden \& Smock, 1991). Therefore, 
wives might be discouraged by the consequences of divorce and less inclined to end their marriages, even if they are unhappy (Sanchez \& Gager, 2000). On the other hand, even though social and economic changes have reduced husbands' power in marriage, male privilege is still expected to protect men against the detrimental effects of a bad marriage. Therefore, men might prefer an unsatisfactory marriage to no marriage at all, and, thus wives' assessments of their relationship might be more important in determining marital success (Nock, 1998). I used couple-level measures for each variable from both husbands and wives. Measuring the relative characteristics of husbands and wives has several benefits. First, we can test the effect of spouses having consistent or conflicting views on marital dissolution. Second, it highlights the role of gender in married couples' assessments of their relationships (Brown, 2000). Despite these different approaches and findings, I expect to find that consistency between spouses' reports is correlated with lower marital dissolution; however, conflicting reports are correlated with higher marital dissolution. I also expect to find that, when there is inconsistency between spouses' reports in gender ideology and marital interaction, wives' assessments of the relationship determine marital dissolution (Hypothesis 5).

\section{Data and Methods}

This study used data from the first two waves of the National Survey of Families and Households (NSFH). The NSFH is a national sample that includes 13,007 primary respondents, aged 19 and older, who were first interviewed in 1987-1988. The sample includes a main cross-section of 9643 households, and oversamples Blacks, Puerto Ricans, Mexican Americans, single-parent families, families with step-children, cohabiting couples, and recently married persons. In Wave 1, one adult per household was randomly selected as the primary respondent. In addition, a shorter self-administered questionnaire was given to the respondent's spouse or cohabiting partner. Wave 2 (19921994) included interviews with the original respondents from Wave 1, the current spouse or cohabiting partner, and, in cases where the relationship from Wave 1 had ended, with spouses or partners from the previous relationships. This study's sample included the married primary respondents from Wave $1(\mathrm{~N}=$ 6877 ) whose spouses completed the questionnaire $(\mathrm{N}=5637)$; this constitutes 82 percent of the married couples surveyed. From the 5637 married couples who fit these criteria, this study's sample was limited to the respondents who had an identifiable marital status at Wave 2 because at least one member of the original couple was interviewed $(\mathrm{N}=4581)$. This group made up 81 percent of the married couples who completed the questionnaire. In addition, there were too few individuals belonging to American Indian or Asian racial groups; thus, they were removed from the sample (both husbands $(\mathrm{N}=61)$ and wives $(\mathrm{N}=29)$ ), leaving a sample of 4491 couples. Overall, the sample contains Whites, African Americans, and Hispanic respondents.

The use of this dataset has several advantages. First, unlike many other studies, this study collected data from both wives and husbands. It is important to include both spouses' reports because their reports might vary, and each may affect marital outcomes differently. Second, the NSFH includes indicators of many aspects of family life, including detailed individual characteristics, marital experiences, employment histories, and information about employment and income (Sweet, Bumpass, \&
Call, 1988). Therefore, the NSFH is an excellent source of data for analyzing the determinants of marital disruption. Despite the many advantages of using NSFH data, there are some limitations. One limitation is that I did not use the third wave of NSFH data (2001-2003). By using the third wave, studies might investigate data on married couples at Wave 1 and changes in employment, marital interaction, and gender ideology between the first two waves, and analyze the effects of these changes on marital outcomes in Wave 3. Thus, these analyses could test the causal relationship between wives' work hours and marital dissolution. In addition, this would permit researchers to examine whether the adverse effects of wives' work hours may have decreased in recent years, and also test whether it is among those unstable marriages that the wives work longer hours to be economically independent.

This study uses only the first two waves of the NSFH data because data for the third wave from 2001-2003 (NSFH3; Sweet \& Bumpass, 2002) were collected through telephone interviews with only primary respondents who were either above age 45 or had a child who was interviewed in wave 2 , as well as with their spouses and their previously interviewed children. Therefore, the sample size of the third wave survey is considerably lower than in the first two waves. Given the attrition from the third wave, the serious limitations of this data set may increase in future waves of data. A second limitation is that the initial wave of the NSFH data is now more than fifteen years old, which raises the question of whether patterns documented using these data are valid for today's marriages. From Amato, Johnson, Booth, And Rogers' (2003) comparison of marrieds from samples drawn in 1980 and 2000, it appears that divorce proneness has not changed much. The proportion of women who worked outside their homes increased rapidly from the 1960 s to the 1990 s, but in the 1990 s, women's labor-force participation rate leveled off, and even slightly decreased in the early 2000s (Percheski, 2008; Vere, 2007). Thus, as the purpose of our analysis is to examine the effect of wives' work hours on marital dissolution, I can be more confident that the findings of this study are applicable to today's marriages.

\section{Handling Missing Data}

Contrary to conventional methods, this study imputed missing values using the ICE (imputation by chained equations) multiple-imputation scheme in STATA. This procedure generates five data sets in which missing information is imputed by regressing each variable with missing data on all observed variables, and adding random error to the imputed values to maintain variability. This approach allowed me to use the study's entire sample $(\mathrm{N}=4491$ married couples $)$.

\section{Measurement of Variables}

Table 1 summarizes the measurement of the variables used in this analysis. With the exception of the dependent variable, marital dissolution, all of the variables were measured at Wave 1. The dependent variable measures the marital status of the couples at Wave 2, thereby distinguishing between couples who separated or divorced from those who remained married at Wave 2.

\section{Independent Variables}

\section{Wives' Work Hours}

The primary independent variable was wives' work hours. 


\section{YUCEL}

Table 1.

Measurement of variables.

\begin{tabular}{ll}
\hline $\begin{array}{l}\text { Variables } \\
\text { Dependent variable } \\
\text { Marital dissolution }\end{array}$ & Measurement \\
$\begin{array}{l}\text { Independent variables } \\
\text { Wives' work hours }\end{array}$ & Dummy variable was coded 1 if permanent separation or divorce took place between Waves 1 and 2 and 0 if they stayed marrie \\
Marital interaction & One item asking, "During the past month, about how often did you and your spouse spend time alone with each other, talking, or \\
sharing an activity?" (1 = never to $6=$ almost every day). Dummy variables: both spouses have high marital interaction; both \\
spouses have low marital interaction; wives have high and husbands have low marital interaction; husbands have high and wive \\
have low marital interaction. Both spouses reporting high marital interaction is the reference category. \\
Four items indicating how much they agree with the first four statements $(1=$ strongly agree to $5=$ strongly disagree) and \\
two items indicating how much they approve of the final two circumstances (1 = strongly approve to $7=$ strongly disapprove). \\
1) "It is much better for everyone if the man earns the main living, and the woman takes care of the home and family." \\
2) "Preschool children are likely to suffer if their mothers are employed." \\
3) "If a husband and a wife both work full-time, they should share household tasks equally.", \\
4) "Parents should encourage just as much independence from their daughters as their sons." \\
5) "Mothers who work full-time when their youngest child is under age 5." \\
6) "Mothers who work part-time when their youngest child is under age 5." \\
Dummy variables: both spouses egalitarian; both spouses moderate; both spouses traditional; wives have more egalitarian \\
views than their husbands; husbands have more egalitarian views than their wives. Both spouses sharing traditional views \\
is the reference category.
\end{tabular}

Control variables

Age of the youngest child living in the household

Dummy variables: the presence of the youngest child under six years old living in the household; children aged between six and twelve years old; children aged between thirteen and seventeen years old; and childless couples (couples who have no children living in the household, or the youngest child living in the household is at least 18 years old). Childless couples are the reference category.

Husbands' work hours Husbands' hours worked in the previous week if that is the usual number of hours worked; usual hours worked per week if otherwise.

Duration of marriage Continuous measure, in years, of the length of a couple's marriage until the date of the interview. I used a logarithmic transformation due to its skew.

Age at marriage Dummy variables: both spouses were younger than 20 when married; the wife, but not the husband, was less than 20 when married; the husband, not the wife, was less than 20 when married; and both spouses married at age 20 or older. Both spouses marrying at age 20 or older is the reference category.

Wives' education Dummy variables: wife has less than a high school diploma; wife has a high school diploma; wife has some college; wife has a college degree or above. Wife having a college degree or above is the reference category.

Husbands' education relative Continuous variable measured by the difference between husbands' and wives' education in degree. to wives' education

Marital order

Dummy variables: both spouses are in their first marriage; both spouses are remarried; husband is in his first marriage, and wife is remarried; wife is in her first marriage, and husband is remarried. Both spouses being in their first marriage is the reference category.

Race-ethnicity

Dummy variables: both spouses are White; both spouses are Black; both spouses are Hispanic; spouses are from different races. Both spouses being White is the reference category.

Total income of the Dummy variables: total income is $\$ 30,000$ or less; between $\$ 30,001$ and $\$ 50,000$; or over $\$ 50,000$. A total income of household over $\$ 50,000$ is the reference category.

The following question was administered to the primary respondent and spouse: "How many hours do you usually work per week?" This variable was treated as continuous. To test the nonlinear effect of wives' work hours, I coded this variable into four dummies: not employed (0 hours), part time (less than 35 hours), full time (between 35 and 40 hours), and overtime (more than 40 hours per week). The results showed that there is a linear effect; thus, I continued to treat wives' work hours as continuous. Wives' work hours were centered (deviated from the mean), and I then created multiplicative interaction terms to examine the hypothesized moderator effects. This approach reduces multi-colinearity among the predictors (Aiken \& West, 1991) and aids in the interpretation of results (Cohen, Cohen, West, \& Aiken, 2003)

\section{Marital Interaction}

Marital interaction was measured by asking the primary re- spondent and spouse how often they spend time alone together $(1=$ never to $6=$ almost every day). Among both genders, 75 percent reported spending time with their spouses almost every day. With such a skewed distribution, I create a dummy variable that coded 1 for the response, "almost every day," and 0 otherwise for both genders. Spending time with a spouse almost every day was coded as high marital interaction, and spending time with a spouse less often was coded as low marital interaction. I then created a couple-level measure of marital interaction with four dichotomous variables (see Table 1).

\section{Gender Ideology}

Both the primary respondents and their spouses were asked how much they agreed with six statements measuring gender ideology. Each item was coded so that higher scores indicated a more egalitarian gender ideology. The indicators were standardized and totaled to create a continuous gender ideology 
index for husbands and wives, respectively. The scale ranged from -13.69 to 8.84 for wives and from -12.55 to 10.41 for husbands. The alpha level was .67 for wives and .65 for husbands. Since the gender distribution was almost normal for both gender ideology scales, I divided this index into three equal parts: the lowest third was traditional, the middle third was a transitional (moderate) gender ideology, and the highest third represented an egalitarian gender ideology (Greenstein, 1995). I created a couple-level measure of gender ideology with five dichotomous variables (see Table 1).

\section{Control Variables}

Several control variables were selected based on their association with wives' work hours and marital dissolution in earlier empirical studies. They include: age of the youngest child living in the household, husband's work hours, log of marital duration, age at marriage, wife's education, husband's education relative to his wife's, marital order, race-ethnicity, and total household income (see Table 1).

\section{Results}

\section{Descriptive Findings}

Table 2 displays the means and standard deviations for the variables in this analysis for two subsamples: couples who remained married and couples who separated or divorced. Twelve percent of marriages ended in separation or divorce between Waves 1 and $2(\mathrm{~N}=555)$. The table shows t-tests for continuous variables and chi-square tests for the categorical variables, to test whether the means and distributions in these groups were significantly different.

Table 2.

Descriptive statistics of independent variables in the analysis.

\begin{tabular}{|c|c|c|c|c|}
\hline & \multicolumn{2}{|c|}{ Still married at Wave 2} & \multicolumn{2}{|c|}{ Divorced or separated at Wave 2} \\
\hline & Mean & Standard deviation & Mean & Standard deviation \\
\hline \multicolumn{5}{|l|}{ Independent variables } \\
\hline Wives' work hours & $21.46^{* * *}$ & 20.31 & $25.46^{* * *}$ & 19.85 \\
\hline \multicolumn{5}{|l|}{ Marital interaction } \\
\hline Both spouses have high marital interaction ${ }^{a}$ & $0.38^{* * *}$ & 0.49 & $0.22^{* * *}$ & 0.42 \\
\hline Both spouses have low marital interaction & $0.34^{* * *}$ & 0.47 & $0.47^{* * *}$ & 0.50 \\
\hline Husbands have low and wives have high marital interaction & 0.16 & 0.37 & 0.14 & 0.34 \\
\hline \multicolumn{5}{|l|}{ Gender ideology } \\
\hline Both spouses are traditional $^{\mathrm{b}}$ & $0.21^{* * *}$ & 0.40 & $0.12^{* * *}$ & 0.32 \\
\hline Both spouses are moderate & 0.13 & 0.34 & 0.11 & 0.32 \\
\hline Both spouses are egalitarian & $0.17^{*}$ & 0.38 & $0.22^{*}$ & 0.41 \\
\hline Wives with a more egalitarian ideology than their husbands & $0.23^{* * *}$ & 0.42 & $0.31^{* * *}$ & 0.46 \\
\hline Husbands with a more egalitarian ideology than their wives & 0.26 & 0.44 & 0.24 & 0.43 \\
\hline \multicolumn{5}{|l|}{ Control variables } \\
\hline \multicolumn{5}{|l|}{ Age of youngest child living in the household } \\
\hline Youngest child under 6 years old & $0.30^{* * *}$ & 0.46 & $0.44^{* * *}$ & 0.50 \\
\hline Youngest child between 6 and 12 years old & $0.17^{*}$ & 0.37 & $0.21^{*}$ & 0.40 \\
\hline Youngest child between 13 and 17 years old & 0.09 & 0.29 & 0.07 & 0.26 \\
\hline Husbands' work hours & $36.86^{* * *}$ & 19.71 & $41.24^{* * *}$ & 17.20 \\
\hline Marital duration (log) & $2.60^{* * *}$ & 0.01 & $1.98^{* * *}$ & 0.03 \\
\hline \multicolumn{5}{|l|}{ Age at current marriage } \\
\hline Both over $20^{\mathrm{d}}$ & $0.68^{* * *}$ & 0.47 & $0.60^{* * *}$ & 0.49 \\
\hline Both younger than 20 & 0.12 & 0.33 & 0.14 & 0.35 \\
\hline Spouses are not the same age & $0.20^{* *}$ & 0.40 & $0.26^{* *}$ & 0.44 \\
\hline \multicolumn{5}{|l|}{ Wives' education } \\
\hline Wife has college degree or above $\mathrm{e}^{\mathrm{e}}$ & $0.23^{* *}$ & 0.42 & $0.19^{* *}$ & 0.39 \\
\hline Wife has some college & 0.21 & 0.41 & 0.20 & 0.40 \\
\hline Wife is a high school graduate & 0.40 & 0.49 & 0.42 & 0.49 \\
\hline Wife has less than a high school diploma & 0.16 & 0.37 & 0.19 & 0.40 \\
\hline Husbands' education relative to wives' education & 0.07 & 0.98 & 0.05 & 1.04 \\
\hline \multicolumn{5}{|l|}{ Marital order } \\
\hline Both spouses in first marriage ${ }^{\mathrm{f}}$ & $0.71^{* * *}$ & 0.45 & $0.58^{* * *}$ & 0.49 \\
\hline \multicolumn{5}{|l|}{ Race-ethnicity } \\
\hline Both spouses White ${ }^{\mathrm{g}}$ & $0.83^{* *}$ & 0.37 & $0.79^{* *}$ & 0.40 \\
\hline Both spouse Black & $0.09^{*}$ & 0.28 & $0.12^{*}$ & 0.32 \\
\hline Both spouses Hispanic & 0.05 & 0.21 & 0.04 & 0.20 \\
\hline Spouses not in the same racial-ethnic group & $0.03^{* *}$ & 0.17 & $0.05^{* *}$ & 0.22 \\
\hline \multicolumn{5}{|l|}{ Total household income } \\
\hline Total Income is over $\$ 50,000^{\mathrm{h}}$ & 0.22 & 0.41 & 0.20 & 0.39 \\
\hline Total Income is $\$ 30,000$ or less & $0.46^{* *}$ & 0.50 & $0.53^{* *}$ & 0.50 \\
\hline Total Income is between $\$ 30,001$ and $\$ 50,000$ & $0.32^{*}$ & 0.46 & $0.27^{*}$ & 0.44 \\
\hline Total N & 3936 & 3936 & 555 & 555 \\
\hline
\end{tabular}

Based on one of the imputed data sets $(\mathrm{N}=4491)$. I reported $\mathrm{t}$ tests for continuous variables and chi square tests for the categorical variables. Letter superscripts show the reference group for each variable. ${ }^{* * *} p<.001 ;{ }^{* *} p<.01 ;{ }^{*} p<.05$ (two-tailed test). 


\section{YUCEL}

Compared to stable married couples, divorcing couples averaged longer weekly work hours and were more likely to report low marital interaction (both spouses and wives only) and egalitarian views (both spouses and wives only). These results support this study's hypotheses. Divorcing couples were more likely to be low-income, remarried, heterogamous in terms of race and age, and have preschoolers in the household; they were also more likely to have been married for fewer years at Wave 1 and to include wives with less education. These descriptive characteristics are consistent with theoretical arguments and previous research findings. In what follows, I examine these relationships in a multivariate context.

\section{Logistic Models}

Because the dependent variable is a dichotomous variable (1 $=$ separated or divorced, $0=$ remained married), all the models were estimated using logistic regression. Table 3 displays the unstandardized logistic regression coefficients and odd ratios (calculated as $\mathrm{e}^{\mathrm{x}}$ ).

\section{Hypothesis 1: Wives' Work Hours and Marital Dissolution}

The bivariate logistic regression between wives' work hours and marital dissolution (not shown) shows a positive and significant association between wives' work hours and marital dissolution. For instance, wives who work 40 hours per week are around 49 percent $\left[100 *\left(\mathrm{e}^{\left(.010^{*} 40\right)}-1\right)\right]$ more likely to dissolve their marriages than those who do not work at all ( $p$ $<.001)$. Net of all the couple-level control measures, the positive association between wives' work hours and marital dissolution is still significant, but the coefficient size and the significance levels are reduced (Model 1). After this adjustment, wives who work 40 hours per week are around 27 percent $\left[100 *\left(\mathrm{e}^{(.006 * 40)}-1\right)\right]$ more likely to dissolve their marriages than those who do not work at all $(p<.05)$. All the control variables

Table 3.

Unstandardized coefficients for the logistic regression of wives' work hours, marital interaction, gender ideology and control variables on marital dissolution $(\mathrm{N}=4491)$.

\begin{tabular}{|c|c|c|c|c|c|c|c|c|c|c|}
\hline & Model 1 & & Model 2 & & Model 3 & & Model 4 & & Model 5 & \\
\hline & Logit & Odds & Logit & Odds & Logit & Odds & Logit & Odds & Logit & Odds \\
\hline Wives' work hours & $\begin{array}{l}0.006^{*} \\
(0.003)\end{array}$ & 1.01 & $\begin{array}{l}0.004 \\
(0.003)\end{array}$ & 1.00 & $\begin{array}{l}0.004 \\
(0.003)\end{array}$ & 1.00 & $\begin{array}{l}0.003 \\
(0.008)\end{array}$ & 1.00 & $\begin{array}{l}0.003 \\
(0.003)\end{array}$ & 1.00 \\
\hline \multicolumn{11}{|l|}{ Marital interaction } \\
\hline Both low marital interaction & & & $\begin{array}{l}0.678^{* * *} \\
(0.136)\end{array}$ & 1.97 & & & & & $\begin{array}{l}0.670^{* * *} \\
(0.136)\end{array}$ & 1.95 \\
\hline Husband low, wife high marital interaction & & & $\begin{array}{l}0.189 \\
(0.165)\end{array}$ & 1.21 & & & & & $\begin{array}{l}0.179 \\
(0.166)\end{array}$ & 1.20 \\
\hline Husband high, wife low marital interaction & & & $\begin{array}{l}0.694^{* * *} \\
(0.159)\end{array}$ & 2.00 & & & & & $\begin{array}{l}0.684^{* * *} \\
(0.160)\end{array}$ & 1.98 \\
\hline \multicolumn{11}{|l|}{ Gender ideology } \\
\hline Both moderate & & & & & $\begin{array}{l}0.191 \\
(0.203)\end{array}$ & 1.21 & $\begin{array}{l}0.196 \\
(0.211)\end{array}$ & 1.22 & $\begin{array}{l}0.171 \\
(0.204)\end{array}$ & 1.19 \\
\hline Both egalitarian & & & & & $\begin{array}{l}0.475^{* *} \\
(0.184)\end{array}$ & 1.61 & $\begin{array}{l}0.579^{* *} \\
(0.198)\end{array}$ & 1.78 & $\begin{array}{l}0.482^{* *} \\
(0.186)\end{array}$ & 1.62 \\
\hline $\begin{array}{l}\text { Wives with more egalitarian views } \\
\text { than their husbands }\end{array}$ & & & & & $\begin{array}{l}0.555^{* * *} \\
(0.170)\end{array}$ & 1.74 & $\begin{array}{l}0.556^{* *} \\
(0.179)\end{array}$ & 1.74 & $\begin{array}{l}0.519^{* *} \\
(0.171)\end{array}$ & 1.68 \\
\hline $\begin{array}{l}\text { Husband with more egalitarian } \\
\text { views than their wives }\end{array}$ & & & & & $\begin{array}{l}0.274 \\
(0.176)\end{array}$ & 1.31 & $\begin{array}{l}0.279 \\
(0.192)\end{array}$ & 1.32 & $\begin{array}{l}0.241 \\
(0.177)\end{array}$ & 1.27 \\
\hline Wives' hours ${ }^{*}$ both moderate & & & & & & & $\begin{array}{l}0.006 \\
(0.011)\end{array}$ & 1.01 & & \\
\hline Wives' hours ${ }^{*}$ both egalitarian & & & & & & & $\begin{array}{l}-0.008 \\
(0.011)\end{array}$ & 0.99 & & \\
\hline $\begin{array}{l}\text { Wives' hours }{ }^{*} \text { wives with more } \\
\text { egalitarian views than their husbands }\end{array}$ & & & & & & & $\begin{array}{l}0.003 \\
(0.009)\end{array}$ & 1.00 & & \\
\hline $\begin{array}{l}\text { Wives' hours }{ }^{*} \text { husbands with more } \\
\text { egalitarian views than their wives }\end{array}$ & & & & & & & $\begin{array}{l}0.002 \\
(0.010)\end{array}$ & 1.00 & & \\
\hline Intercept & $-0.841^{* * *}$ & & $-0.960^{* * *}$ & & $-1.247^{* * *}$ & & $-1.252^{* * *}$ & & $-1.352^{* * *}$ & \\
\hline-2 Log Likelihood & 1485.206 & & 1467.789 & & 1477.293 & & 1475.010 & & 1460.543 & \\
\hline$\chi^{2}$ & $388.842^{* * *}$ & & $423.676^{* * *}$ & & $404.670^{* * *}$ & & $409.234^{* * *}$ & & $438.168^{* * *}$ & \\
\hline $\mathrm{DF}$ & 20 & & 23 & & 24 & & 28 & & 27 & \\
\hline Pseudo- $\mathrm{R}^{2}$ & 0.12 & & 0.13 & & 0.12 & & 0.12 & & 0.13 & \\
\hline
\end{tabular}

Standard errors are in parentheses. All models include the following control variables (not shown): age of the youngest child living in the household, husbands' work hours, $\log$ of marital duration, age at marriage, wives' education, husbands' education relative to wives', marital order, race-ethnicity, and total household income. ${ }^{* * *} p<.001 ;{ }^{* *} p$ $<.01 ;{ }^{*} p<.05$ (two-tailed test). 
operated in the expected direction. Model 1 supports the first hypothesis that there is a positive and significant relationship between wives' work hours and marital dissolution; this association holds net of all controls.

\section{Hypothesis 2: The Mediating Effect of Marital Interaction}

Model 2 tested the mediating effect of marital interaction using the attachment hypothesis. Controlling for marital interaction, the effect of wives' work hours is no longer significant, which suggests that couples' marital interaction mediates this effect. When both spouses report low marital interaction and when only wives report low marital interaction, couples are about twice as likely to dissolve their marriages $(p<.001)$. In contrast, when only husbands report low marital interaction, couples are not significantly more likely to dissolve their marriages than are spouses who both report high marital interaction. In addition, marital interaction measures fully mediate the effect of the presence of a child under 6 years old and partially mediate the effect of a child between 6 and 12 years old on marital dissolution (not shown in Table 3). Once I added the marital interaction measures, couples with a preschooler living in the household were no longer more likely to dissolve their marriages. Furthermore, couples with children between $6-12$ years old were about 39 percent more likely to dissolve their marriages than childless couples, but the significance effect was reduced ( $p<.05$; not shown). Model 2 shows that the effect of wives' work hours on marital dissolution operates through decreased marital interaction (for both spouses and wives only). Hypothesis 2 is therefore supported, and the inclusion of marital interaction dummies significantly improves the previous model (chi-square change between Model 1 and Model $2=$ 34.83 with 3 df, $p<.001$ ).

\section{Hypothesis 3: The Mediating Effect of Gender Ideology}

Model 3 tested the additive effect of gender ideology and supported the gender role strain hypothesis. When the model controlled for couple-level control variables and couples' gender ideology, the effect of wives' work hours was no longer significant. This finding suggests that the effect of wives' work hours on marital dissolution is mediated by couples' gender ideology. Specifically, the effect of wives' increased work hours on marital dissolution operates through increased egalitarianism (for both spouses and wives only), which is consistent with the gender role strain argument. Couples' gender ideology dummies mediate the effect of wives' work hours on marital dissolution (as shown in Model 3). Couples who share an egalitarian perspective are around 61 percent more likely to end their marriages than spouses with a traditional outlook $(p<.01)$, while couples in which wives have a more egalitarian viewpoint than their husbands are about 74 percent more likely to end their marriages than couples who share a traditional viewpoint $(p<.001)$. The effects of the other control variables remain the same as in Model 1. The pseudo R-square also remained the same, but the chi-square change between Model 1 and Model 3 was 15.83 with $4 \mathrm{df}$ and is significant $(p<.01)$. Thus, the inclusion of the additive effects of gender ideology improved on Model 1, and Hypothesis 3 was supported. Consistent with the role strain theory, gender egalitarianism (for both spouses and wives only) mediates the effect of wives' work hours on marital dissolution.

\section{Hypothesis 4: The Moderating Effect of Gender Ideology}

To test the multiplicative effect of gender ideology, Model 4 included the interaction terms between wives' work hours and gender ideology variables. None of the interactions between gender ideology and wives' work hours were significant. I can therefore conclude that the effect of wives' work hours on marital dissolution does not differ across couples' gender ideology. The chi-square change between Model 3 and Model 4 was 4.56 with $4 \mathrm{df}$ and is not significant. The insignificant interaction terms between wives' work hours and gender ideology did not improve on the previous model. Thus, the interaction terms between wives' work hours and gender ideology dummies were excluded from the subsequent analyses. Overall, this result does not support the ideological consistency hypothesis, and Hypothesis 4 is not supported.

\section{Hypothesis 5: Comparison of Wives' or Husbands' Assessments of Their Relationship in Predicting Marital Dissolution among Couples with Inconsistent Reports}

I included marital interaction and gender ideology dummies in the final model, Model 5. The inclusion of these variables significantly improved Model 3 (chi-square change between Model 3 and Model $5=33.50$ with $3 \mathrm{df}, p<.001$ ). This model shows that the simultaneous inclusion of marital interaction measures and gender ideology measures added significantly to our prediction of marital dissolution. Model 5 shows that couples who share egalitarian ideas and couples with more egalitarian wives are around 62 and 68 percent (respectively) more likely to dissolve their marriages, compared with spouses who share a traditional outlook $(p<.01)$. In addition, spouses who both report lower marital interaction and couples in which only the wife reports low marital interaction are around twice as likely to dissolve their marriages than spouses who both give reports of high marital interaction $(p<.001)$.

Sometimes couples give different reports of relationship assessment. For couples who evaluate their marriages differently, is marital dissolution equally affected by the husbands' and wives' reports? In addition, is marital dissolution equally affected when husbands report more egalitarianism (than their wives) versus when wives report more egalitarianism (than their husbands)? This study's results suggest that when wives report low levels of marital interaction, marital dissolution is more likely. However, when husbands report low levels of marital interaction, marital dissolution is more likely only when their wives agree. Similarly, when wives report egalitarian gender roles, regardless of their husbands' gender roles, marital dissolution is more common. In contrast, a husband's egalitarian gender ideology is only a significant predictor of marital dissolution when his wife also espouses an egalitarian gender role. Overall, when there is inconsistency between spouses' reports, the effect of relationship assessment on marital dissolution is contingent on gender. This finding signals the importance of wives' assessments of their relationships on marital dissolution. Thus, Hypothesis 5 is supported.

\section{Discussion and Conclusion}

Despite inconsistent findings, some prior research has concluded that wives' work hours are correlated with higher marital dissolution. However, researchers have not yet clarified the underlying mechanisms that link wives' work hours to marital dissolution. The results in this study suggest that wives' in- 
creased work hours are positively correlated with higher marital dissolution. In addition, the effect of wives' work hours on marital dissolution operates through low marital interaction (for both spouses and for wives only). This study also found that the effect of wives' increased work hours on marital dissolution is mediated through higher gender egalitarianism (for both spouses and for wives only). Lastly, the results suggest the importance of women's assessment of their relationships on marital dissolution. Specifically, this study concludes that, among couples with different perceptions of their marriages, wives' assessments of low marital interaction and egalitarian gender ideology both predict marital dissolution, and that husbands' assessments alone have no significant effect.

One of the most rapid changes since the twentieth century in the United States has been the substantial increase in married women's participation in the labor force. About 60 percent of all women are in the labor force, compared with nearly 75 percent of all men (US Department of Labor, Bureau of Labor Statistics, 2008). Researchers have long studied wives' employment, which has been considered a determinant of marital instability. This study extends and enriches the existing literature in two important ways, by testing some of the mediating and moderating mechanisms to better understand this relationship. The results emphasize the importance of attachment hypothesis and role strain theory. First, this study found that marriages face the challenges of the time factor (i.e., reduced time for marital interaction) associated with wives' employment and of changes in gender ideologies as more women participate in the labor force. Second, this study builds upon prior studies by using couple-level measures and data from both husbands and wives. In doing so, this study differentiates the effects of each spouse's views on marital dissolution when there is either consistency or inconsistency between couples' reports of gender ideology and marital interaction. The results suggest that perceptions of marriages vary between husbands and wives. Therefore, this study suggests the importance of future research taking the relative characteristics of husbands and wives into account.

Despite these contributions, this study also has some limitations. Although the results suggest that wives' increased work hours outside the home might decrease marital interaction and increase gender egalitarianism, I cannot make a causal argument about these correlations because the variables for wives' work hours and gender ideology were both measured at the same time. Greene and Quester (1982) also found that women who think about divorce are more likely to be in the labor force and to work more hours than women who do not think about divorce. I would need more than two waves of data to rule out the causal role of wives' work hours on marital dissolution. Thus, the results presented in this study should be classified as "correlates" and not true "causes" of marital dissolution.

This study has opened new avenues for future research. For example, would a sample of first-marriage couples who have been married for a short duration yield the same results? Couples who are older, have been married for a long time, and are in their first marriages are less likely to divorce overall, and may be less affected by variations in wives' work hours. Overall, the results do not suggest that these are the only two mechanisms that explain this association between wives' increased work hours and marital dissolution. For example, the time constraints associated with wives' work hours might also create stress associated with not having enough time for child care and housework. This stress leads to weaker perceptions of marriage and thus increases the likelihood of martial dissolution. On the other hand, wives' increased gender egalitarianism might lead them to perceive their marriages as unfair; this perception lowers marital quality and increases the risk of marital dissolution. Future research could also consider the mediating and/or moderating effects of other indicators such as wives' education (Bumpass, Sweet, \& Cherlin, 1991), wives' economic resources (Teachman, 2010) and work schedule (Kalil, ZiolGuest, \& Epstein, 2010; Kingston \& Nock, 1987; Presser, 2000; White \& Keith, 1990), the division of household labor (Cunningham, 2007), and perceptions of fairness within the marriage (Blair, 1993; Greenstein, 1996a). These analyses would shed additional light on the conditions under which wives' work hours predict marital dissolution. The same question could also be explored using the third wave of the NSFH. Studies might investigate data on married couples at Wave 1 and changes in employment, marital interaction, and gender ideology between the first two waves, and analyze the effects of these changes on marital outcomes in Wave 3. These analyses would be able to test causality and permit researchers to examine whether the adverse effects of wives' work hours may have decreased in recent years. However, given the attrition from the third wave, the serious limitations of the NSFH data set may be exacerbated in future waves of data.

These results suggest that the relational tensions associated with wives' increased work hours and the associated gender egalitarianism explain some of the relationships between wives' work hours and marital dissolution. As more women join the labor force, dual-earner families will face more challenges, such as time constraints and ideological change. Although it should be noted that the husbands of employed women and of egalitarian wives participate in more housework and child care (Orbuch \& Eyster, 1997; Pleck, 1985; Presser, 1994) and that there is near equality in spouses' employment statuses, the division of domestic labor (e.g., the household division of labor and child care) is far from equal (Bianchi, Milkie, Sayer, \& Robinson, 2000). It is still the case that, in response to wives' employment change, husbands increase their participation in domestic work much less than wives decrease theirs. This finding indicates that there is a lag in husbands' adaptation to the change in their wives' employment status (i.e., when wives enter full-time, paid work) (Gershuny, Bittman, \& Brice, 2005). Overall, wives might still experience time pressure and the need to balance work and family roles. This finding indicates that husbands need to take on more of the responsibilities that are traditionally associated with women, such as housework and child care. Unless these adaptations take place, it is possible that wives will be less satisfied in their marriages, which decreases marital interaction and increases the likelihood of marital dissolution.

This study emphasizes the time factor of wives' employment, which is found to predict marital dissolution. This factor leads not only to decreased marital interaction but also may cause stress, especially for wives, associated with the need to balance work and family roles. Thus, as more women join the labor force, employers might provide family-friendly benefits, such as emergency child-care, to reduce some of the negative consequences of these time constraints. Moreover, these results also suggest that spouses' relationship assessments differ. Thus, it is important for future studies of relationship outcomes to include information from both husbands and wives, not just 
information from one spouse.

There has indeed been extensive research on the question of how wives' work hours may be linked to marital dissolution. Still, this study takes an important step forward by emphasizing that more research is needed to better understand the mediating and moderating mechanisms between wives' work hours and marital dissolution. In addition, this study's use of data sets such as the NSFH that collect data from both spouses, and its measurement approaches to capture consistency as well as conflict between spouses' views, is critical to further improving research in this area.

\section{Acknowledgements}

I appreciate the comments of Dr. Douglas Downey, Dr. Margaret Gassanov, and Dr. Donna Bobbitt-Zeher.

\section{REFERENCES}

Aiken, L. S., \& West, S. G. (1991). Multiple regression: Testing and interpreting interactions. Thousand Oaks, CA: Sage.

Amato, P. R., Johnson, D. R., Booth, A., \& Rogers, S. J. (2003). Continuity and change in marital quality between 1980 and 2000. Journal of Marriage and Family, 65, 1-22. doi:10.1111/j.1741-3737.2003.00001.x

Bianchi, S. M., Milkie, M. A., Sayer, L. C., \& Robinson, J. P. (2000). Is anyone doing the housework? Trends in gender division of labor. Social Forces, 79, 191-228.

Blair, S. L. (1993). Employment, family, and perceptions of marital quality among husbands and wives. Journal of Family Issues, 14, 189-212. doi:10.1177/019251393014002003

Bolzendahl, C. I., \& Myers, D. J. (2004). Feminist attitudes and support for gender equality: Opinion change in women and men, 1974-1998. Social Forces, 83, 759-790. doi:10.1353/sof.2005.0005

Booth, A., Johnson, D. R., White, L., \& Edwards, J. N. (1984). Women, outside employment, and marital instability. American Journal of Sociology, 90, 567-583. doi:10.1086/228117

Brown, S. L. (2000). Union transitions among cohabitors: The signifycance of relationship assessments and expectations. Journal of Marriage and the Family, 62, 833-846. doi:10.1111/j.1741-3737.2000.00833.x

Bumpass, L., Sweet, J., \& Cherlin, A. (1991). The role of cohabitation in declining rates of marriage. Journal of Marriage and Family, 53, 913-927. doi:10.2307/352997

Bureau of Labor Statistics. (2008). Labor force participation rates, 1975-2008. URL. http://www.bls.gov/opub/working/page3b.htm

Cohen, J., Cohen, P., West, S. G., \& Aiken, L. S. (2003). Applied multiple regression/correlation analysis for the behavioral sciences (3rd ed.). Hillsdale, NJ: Erlbaum.

Coverdill, J. E., Kraft, J. M., \& Manley, K. S. (1996). Employment history, the sex typing of occupations, pay and change in gender-role attitudes: A longitudinal study of young married women. Sociological Focus, 29, 47-60.

Cunningham, M. (2007). Influences of women's employment on the gendered division of household labor over the life course: Evidence from a 31-year panel study. Journal of Family Issues, 28, 422-444. doi: $10.1177 / 0192513 \times 06295198$

Davis, S. N., \& Greenstein, T. N. (2009). Gender ideology: Components, predictors, and consequences. Annual Review of Sociology, 35, 87-105. doi:10.1146/annurev-soc-070308-115920

Duncan, G. J., \& Hoffman, S. D. (1985). A reconsideration of the economic consequences of marital dissolution. Demography, 22, 485-497. doi: $10.2307 / 2061584$

Fan, P., \& Marini, M. M. (2000). Influences on gender-role attitudes during the transition to adulthood. Social Science Research, 29, 258283. doi: $10.1006 /$ ssre. 1999.0669

Gager, C. T., \& Sanchez, L. (2003). Two as one? Couples' perceptions of time spent together, marital quality, and the risk of divorce. Jour- nal of Family Issues, 24, 21-50. doi:10.1177/0192513X02238519

Gershuny, J., Bittman, M., \& Brice, J. (2005). Exit, voice, and suffering: Do couples adapt to changing employment patterns? Journal of Marriage and Family, 67, 656-665. doi:10.1111/j.1741-3737.2005.00160.x

Goode, W. J. (1960). A theory of role strain. American Sociological Review, 25, 483-496. doi:10.2307/2092933

Greenstein, T. N. (1990). Marital disruption and the employment of married women. Journal of Marriage and the Family, 52, 657-676. doi: $10.2307 / 352932$

Greenstein, T. N. (1995). Gender ideology, marital disruption, and the employment of married women. Journal of Marriage and the Family, 57, 31-42. doi: $10.2307 / 353814$

Greenstein, T. N. (1996a). Gender ideology and perceptions of the fairness of the division of labor: Effects on marital quality. Social Forces, 74, 1029-1042.

Greenstein, T. N. (1996b). Husbands' participation in domestic labor: Interactive effects of wives' and husbands' gender ideologies. Journal of Marriage and the Family, 58, 585-595. doi:10.2307/353719

Greene, W. H., \& Quester, A. O. (1982). Divorce risk and wives' labor supply behavior. Social Science Quarterly, 63, 16-27.

Heaton, T. B., \& Blake, A. M. (1999). Gender differences in determinants of marital disruption. Journal of Family Issues, 20, 25-45. doi:10.1177/019251399020001002

Hill, M. S. (1988). Marital stability and spouses' shared time. Journal of Family Issues, 9, 427-451. doi:10.1177/019251388009004001

Hochschild, A. (1989). The second shift: Working parents and the revolution at home. New York, NY: Viking Penguin.

Holden, K. C., \& Smock, P. J. (1991). The economic costs of marital dissolution: Why do women bear a disproportionate cost?" Annual Review of Sociology, 17, 51-78. doi:10.1146/annurev.so.17.080191.000411

Huber, J., \& Spitze, G. (1981). Wives' employment, household behaveiors, and sex-role attitudes. Social Forces, 60, 50-69.

Johnson, J. H. (2004). Do long work hours contribute to divorce? Topics in Economic Analysis and Policy, 4, 1-23. doi: 10.2202/1538-0653.1118

Kalil, A., Ziol-Guest, K. M., \& Epstein, J. L. (2010). Nonstandard work and marital instability: Evidence from the national longitudinal survey of youth. Journal of Marriage and Family, 72, 1289-1300. doi:10.1111/j.1741-3737.2010.00765.x

Kingston, P. W., \& Nock, S. L. (1987). Time together among dual-earner couples. American Sociological Review, 52, 391-400. doi: $10.2307 / 2095358$

Minnotte, K. L., Minnotte, M. C., Pedersen, D. E., Mannon, S. E., \& Kiger, G. (2010). His and her perspectives: Gender ideology, workto-family conflict, and marital satisfaction. Sex Roles, 63, 425-438. doi:10.1007/s11199-010-9818-y

Montalto, C. P., \& Gerner, J. L. (1998). The effect of expected changes in marital status on labor supply decisions of women and men. Journal of Divorce and Remarriage, 28, 25-51. doi: $10.1300 / \mathrm{J} 087 \mathrm{v} 28 \mathrm{n} 0302$

Nock, S. L. (1998). Marriāge in men's lives. New York, NY: Oxford University Press.

Nordenmark, M., \& Nyman, C. (2003). Fair or unfair? Perceived fairness of household division of labour and gender equality among women and men: The Swedish case. European Journal of Women's Studies, 10, 181-209. doi:10.1177/1350506803010002004

Orbuch, T. L., \& Eyster, S. L. (1997). Division of household labor among black couples and white couples. Social Forces, 76, 301-332.

Percheski, C. (2008). Opting out? Cohort differences in professional women's employment rates from 1960 to 2005. American Sociological Review, 73, 497-517. doi:10.1177/000312240807300307

Pleck, J. H. (1985). Working wives, working husbands. Beverly Hills, CA: Sage.

Poortman, A. (2005). How work affects divorce. The mediating role of financial and time pressures. Journal of Family Issues, 26, 168-195. doi: $10.1177 / 0192513 \times 04270228$

Presser, H. B. (1994). Employment schedules among dual-earner spouses and the division of household labor by gender. American Sociological Review, 59, 348-364. doi:10.2307/2095938 


\section{YUCEL}

Presser, H. B. (2000). Nonstandard work schedules and marital instability. Journal of Marriage and the Family, 62, 93-110. doi:10.1111/j.1741-3737.2000.00093.x

Ross, H. L., \& Sawhill, I. V. (1975). Time of transition: The growth of families headed by women. Washington, DC: Urban Institute.

Sanchez, L., \& Gager, C. T. (2000). Hard living, perceived entitlement to a great marriage, and marital dissolution. Journal of Marriage and the Family, 62, 708-722. doi:10.1111/j.1741-3737.2000.00708.x

Sayer, L. C., \& Bianchi, S. M. (2000). Women's economic independence and the probability of divorce: A review and reexamination. Journal of Family Issues, 21, 906-943. doi: $10.1177 / 019251300021007005$

Schmitt, M., Matthias, K., \& Shapiro, A. (2007). Marital interaction in middle and old age: A predictor of marital satisfaction? International Journal of Aging and Human Development, 65, 283-300. doi:10.2190/AG.65.4.a

Sen, B. (2000). How important is anticipation of divorce in married women's labor supply decisions? An intercohort comparison using NLS data. Economics Letters, 67, 209-216. doi:10.1016/S0165-1765(99)00259-1

South, S. J., \& Spitze, G. (1986). Determinants of divorce over the marital life course. American Sociological Review, 51, 583-590. doi: $10.2307 / 2095590$

Spitze, G., \& South, S. J. (1985). Women's employment, time expen- diture, and divorce. Journal of Family Issues, 6, 307-629. doi:10.1177/019251385006003004

Sweet, J. A. \& Bumpass, L. L. (2002). The national survey of families and households-Waves 1, 2, and 3: Data description and documentation. Retrieved from University of Wisconsin-Madison, Center for Demography and Ecology website. http://www.ssc.wisc.edu/nsfh/home.htm

Sweet, J., Bumpass, L., \& Call, V. (1988). The design and content of the national survey of families and households. Center for Demography and Ecology, University of Wisconsin.

Teachman, J. (2010). Wives' economic resources and risk of divorce. Journal of Family Issues, 31, 1305-1323. doi: $10.1177 / 0192513 \times 10370108$

Vere, J. P. (2007). Having it all no longer: Fertility, female labor supply, and the new life choices of generation X. Demography, 44, 821-828. doi:10.1353/dem.2007.0035

Voydanoff, P. (1988). Work role characteristics, family structure demands, and work/family conflict. Journal of Marriage and the Family, 50, 749-761. doi:10.2307/352644

White, L., \& Keith, B. (1990). The effects of shift work on the quality and stability of marital relations. Journal of Marriage and the Family, 52, 453-462. doi:10.2307/353039

Yucel, D. (2012). Wives' work hours and marital dissolution: Differential effects across marital duration. Sociology Mind, 2, 12-22. 